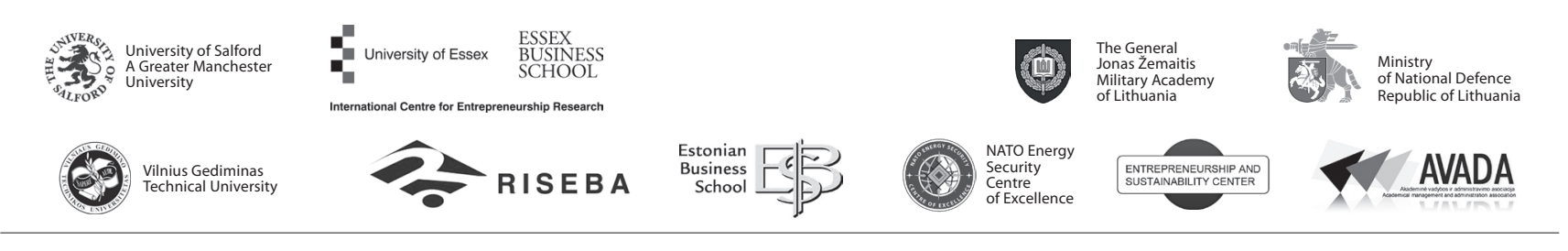

\author{
JOURNAL OF SECURITY AND SUSTAINABILITY ISSUES \\ ISSN 2029-7017 print/ISSN 2029-7025 online \\ 2018 September Volume 8 Number 1 \\ https://doi.org/10.9770/jssi.2018.8.1(5)
}

\title{
ENERGY SECURITY FACETS: VERIFICATION OF HORTICULTURAL WOODEN WASTE POTENTIAL WITH BIOENERGY DEVELOPMENT PURPOSE
}

\author{
Alina Burliai ${ }^{1}$, Oksana Ryabchenko, ${ }^{2,5}$, Peter Bielik², Oleksandr Burliai ${ }^{4}$ \\ ${ }^{1,4}$ Uman National University of Horticulture, Ukraine \\ ${ }^{2}$ Slovak university of Agriculture in Nitra, Slovakia \\ ${ }^{3}$ Slovak university of Agriculture in Nitra, Faculty of Economics and Management, \\ Tr. A. Hlinku 2, 94901 Nitra, Slovakia \\ ${ }^{5}$ Research Centre AgroBioTech, National University of Bioresources and Life Sciences of Ukraine, Kiev, Ukraine \\ E-mails: ${ }^{1}$ aburlyay@gmail.com; ${ }^{2}$ riabchenko_oksana@nubip.edu.ua;
${ }^{3}$ peter.bielik@uniag.sk; ${ }^{4}$ oburlyay@gmail.com
}

Received 16 December 2018; accepted 20 August 2018

\begin{abstract}
The significant volume of bio-waste is coming from horticulture due to the treatment of perennial plantations. Horticulture wooden waste looks like a promising feedstock for the further utilization by bio-based energy sector. Moreover, using waste obtained in the result of-trees' trimming and perforation might provide high economic and environmental impact in the energy balance of the country. Unfortunately, currently, the potential of this wooden waste is not used fully. Partly, this caused with lack of accurate data about available resource especially in the developing countries such as Ukraine. In this study, assessment of energy, economic and geographical potential of horticulture wooden waste was proposed following up to case-study of biomass potential analysis. The research was based on the case study in one region but the obtained results were scaled on the country level. Additionally, it was found that the diversity of methods of waste biomass volume assessment in horticulture depended on the farm type, since highly developed industrial farms and small households carry out gardening on the different ways.
\end{abstract}

Keywords: bio-based energy; bio-waste feedstock; horticulture wooden waste valorization; economic potential; energy potential; geographic potential

Reference to this paper should be made as follows: Burliai, A.; Ryabchenko, O.; Bielik, P.; Burliai, O. 2018. Energy security facets: verification of horticultural wooden waste potential with bioenergy development purpose, Journal of Security and Sustainability Issues 8(1): 55-67. https://doi.org/10.9770/jssi.2018.8.1(5)

JEL Classifications: $\mathrm{O} 13$

\section{Introduction}

1.2. Matter of energy security: Energy security is one of the most important components of the national security. The main risks of energy security, along with water and food security, have social, economic and environmental nature (Šincāns et al. 2016; Dobrovolskienė et al. 2017; Tvaronavičienè et al. 2017; Kisel'áková et al. 2018; Rocha, Neves 2018; Cardoso et al. 2018; Ivanova, Latyshov 2018; Muniz et al. 2018; Monni et al. 2018; Ivanov et al. 2018; Plenkina et al. 2018; Tvaronavičienė 2018; Iorio et al. 2018; Shakhovskaya et al. 2018; Kiseláková et al. 2018). Nowadays, the concerns also might be caused by unpredictable political reconfigurations of leading solid fuel producers as Ukrainian example has shown. As a result, since 2014 energy security in Ukraine have been developed under threat and requires finding the ways out of a critical situation. 
In 2015, the structure of total primary supply of energy resources was characterized by a high part of natural gas $(28.9 \%, 26 \mathrm{mln}$ tons of n.e.) according to the State Statistics Service of Ukraine. The part of nuclear power was $25.5 \%$ ( $23 \mathrm{mln}$ tons of n.e.); coal $-30 \%$ ( $27 \mathrm{mln}$ tons of n.e.); raw oil and petroleum products $-11.6 \%$ (10.5 mln tons of n.e.); biomass (biomass, fuel and waste) - $2.2 \%$ ( $2 \mathrm{mln}$ tons of n.e.); HPS - $1.1 \%$ ( $1 \mathrm{mln}$ tons of n.e.); thermal energy (thermal energy of the environment and waste resources of technogenic origin) $-0.6 \%$ ( $0.5 \mathrm{mln}$ tons of n.e.) and wind and solar energy together $-0.1 \%(0.1 \mathrm{mln}$ tons of n.e.). The total part of all renewable energy sources was 3.6 million tons of n.e. or only $4 \%$. In 2015, from the field of view of limited natural resources in Ukraine, the index of import dependence rate was 51.6\% including supply of nuclear fuel that caused a risk for energy security.

The New Energy Strategy of Ukraine until 2035 "Safety, energy efficiency, competitiveness" expects "increasing the use of biomass in generation of electrical and heat energy". Thus, it is provided that the part of renewable energy sources in Ukraine will be $25 \%$ including biomass, biofuel and waste $-11.5 \%$ by 2035 (Table 1). That is, the importance of biomass production is increasing in Ukraine.

Table 1. Structure of the total primary supply of energy resources of Ukraine, $\%$

\begin{tabular}{|c|c|c|c|c|c|}
\hline Sources of primary energy supply & $\begin{array}{c}2015 \\
\text { (reality) }\end{array}$ & $\begin{array}{c}2020 \\
\text { (forecast) }\end{array}$ & $\begin{array}{c}2025 \\
\text { (forecast) }\end{array}$ & $\begin{array}{c}2030 \\
\text { (forecast) }\end{array}$ & $\begin{array}{c}2035 \\
\text { (forecast) }\end{array}$ \\
\hline Coal & 30.0 & 22.0 & 16,1 & 14.3 & 12.5 \\
\hline Natural gas & 28.9 & 29.3 & 31.0 & 30.8 & 30.2 \\
\hline Petroleum products & 11.6 & 11.5 & 9.2 & 8.2 & 7.3 \\
\hline Atomic energy & 25.5 & 29.3 & 32.2 & 29.7 & 25.0 \\
\hline Biomass, biofuels and waste & 2.2 & 4.9 & 6.9 & 8.8 & 11.5 \\
\hline Solar and wind energy & 0.1 & 1.2 & 2.4 & 5.5 & 10.4 \\
\hline HPS & 1.1 & 1.2 & 1.1 & 1.1 & 1.0 \\
\hline Thermal energy & 0.6 & 0.6 & 1.1 & 1.6 & 2.1 \\
\hline Total & 100 & 100 & 100 & 100 & 100 \\
\hline Including fossil resources & 96 & 92 & 88 & 83 & 75 \\
\hline Including renewable resources & 4 & 8 & 12 & 17 & 25 \\
\hline
\end{tabular}

Source: https://www.kmu.gov.ua/ua/npas/250250456

It should be noted that directions of energy development in Ukraine are in line with the tendencies in energy sector of the EU and meet the criteria of sustainable development. The EU Directive 2009/28/ "On promoting of energy use of renewable sources" created the basis for promoting of renewable energy sources in the EU and established obligatory national target indexes, namely: by 2020, the part of renewable sources of energy in final energy consumption should reach on average to $20 \%$ in EU-28 including in transport - $10 \%$.

Moreover, increase in the part of using renewable energy sources will remain for the further one of the strategic objectives of the economic development in European Union. EU States-Members have already agreed about a new target indicator of the use of renewable energy sources in final energy consumption which should reach at least $27 \%$ in 2030 .

According Eurostatistics information, the part of renewable sources of energy in gross final consumption of energy was $16.7 \%$ in 2015 or it doubled in the last decade. In the context of EU countries, there was broad amplitude of the part of renewable energy sources in gross energy consumption: from $5.0 \%$ in Luxembourg and Malta to $53.9 \%$ in Sweden.

In terms of the European Union countries, Estonia (93.8\%), Lithuania (92.1\%) and Poland (90.1\%) make the largest part of energy from biomass and waste, and the smallest part is produced by Cyprus (31.7\%), Spain $(38.2 \%)$ and Malta (40\%). 
Energy from biomass and waste processing of $64 \%$ is a significant part regarding the structure of renewable energy sources in the EU unlike in Ukraine (Figure 1).

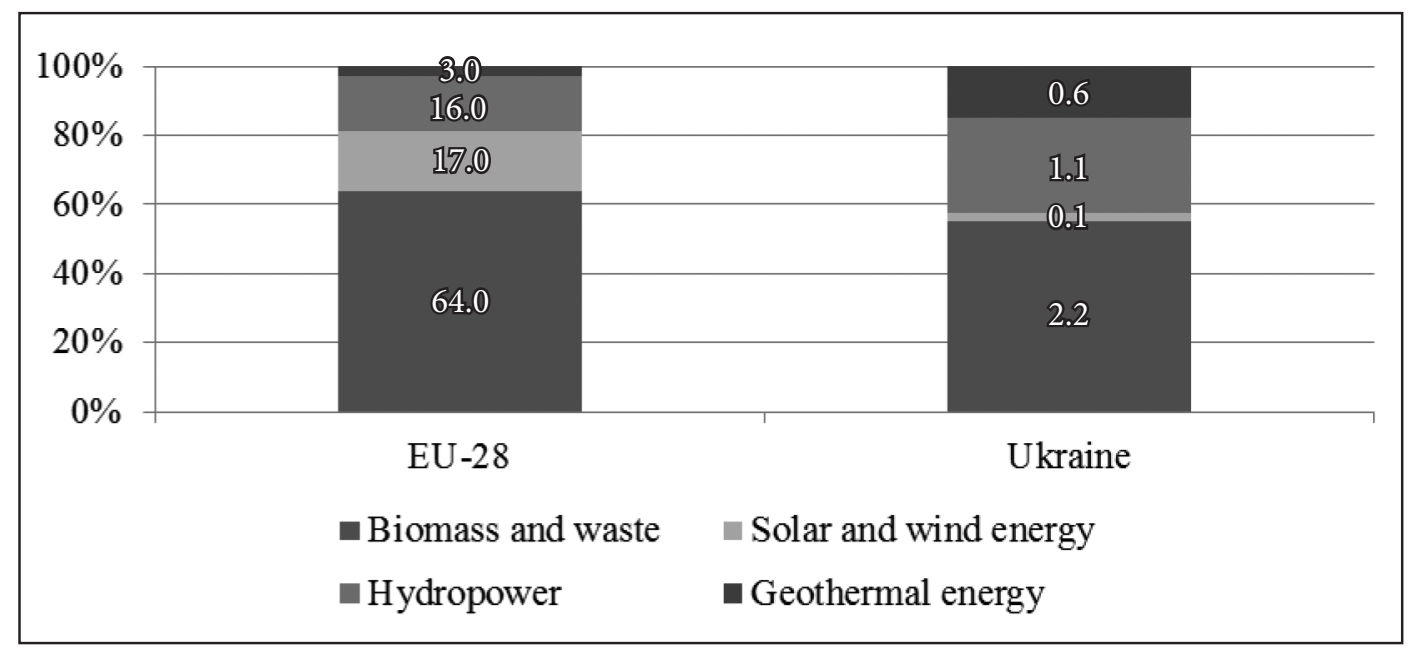

Figure 1. The structure of renewable energy sources in Ukraine and EU-28 in 2015, \%

Source: http://ec.europa.eu/eurostat/web/energy/data/energy-balances

The part of energy from biomass and waste is only $2.2 \%$ in Ukraine. This index is extremely low in the terms on the total expecting potential. Thus, this is important to assess the potential of biomass energy production in Ukraine. However, this is especially important to estimate bio-waste potential regard to energy production as most promising source of renewable energy production as well as which has not cross interests with food security issues.

1.2. Matter of sustainability: Due to the importance of horticulture wooden waste as a renewable feedstock for energy production, it is necessary to understand additional benefits from its utilization such as economics, environmental, social and etc.

From the one hand, energy sources diversification is conditioned by the concept of sustainable development studied by many scientists (Twidell, J. and Weir, T., 2015). At the same time, grousing of biowaste using was targeted to the problem of maximization energy income with simultaneous cost reduction, from the other one. Moreover, Veronika Dornburg and André P.C. Faaij (2001) noted that economic and energy efficiency of biomass using also depended on such key factors as logistics costs, the degree of heat utilization and scale effect which was quite significant.

European countries as well as Brazil, India and USA use biomass widely to energy supply and promote the development of necessary knowledge and technologies. Thus, back in 1998, scientists D.O.Halla and J.I.Scrasea (1998) proved the need to turn to the use of alternative sources of energy. They pointed out that potential resources for bioenergy were large, especially in the countries rich in forests, in highly developed countries where there was a surplus of agricultural land, as well as in many other countries where high yields of biomass could be possible. Therefore, they expected that biomass would become an important source in the future. Potential of global biomass can satisfy one third of the projected global demand for energy in 2050 (Dornburg et al. 2010).

Energy obtained from the wood has become one of the most important types of renewable energy long ago in many countries around the world. Such researchers as Song N. and Aguilar FX. (2017) improved that energy from wood biomass was historically the most significant source of renewable energy in the USA which was used not only for heating but also for electricity production. Global supply of wood biomass could satisfy $2-18 \%$ of world consumption of primary energy needs in 2050 due to available volume. However, it is important to evaluate not only the volume of resources but also the potential effectiveness of their using regards to competition with the other consumer's needs. 
Stock of wooden biomass is significant in some of EU countries. Thus, the total combined available potential in Europe is 76 million $\mathrm{m} 3$ of wood biomass from forests, with additional 90 million $\mathrm{m} 3$ from increasing forest areas and 98 million $\mathrm{m} 3$ from fast-growing plantations (Mola-Yudego et al., 2017). According to their conducted studies, Germany and France showed a high potential from both agriculture and forest; Finland and Sweden had a great potential from forest resources; and Spain, Poland and the UK had a potential from fast-growing plantations.

As was mentioned before, wooden biomass utilisation is a promising branch of energy usage diversification in Ukraine. Following to the data getting from the Ministry of Statistics of Ukraine, agriculture takes a third place due to the its share in the GDP with around $12 \%$. In this study, we were focused on the horticulture bio-waste potential as one of the less studied.

Horticulture is a traditional branch of agriculture in Ukraine which has a centuries-old history. Horticulture industry is well developed almost throughout the country and in recent years its share about $5 \%$ in the total volume of agriculture production. Moreover, it observes enough space and conditions to further its development. There are primarily connected with dissatisfied demand for fruit production in Ukraine and export opportunities of the industry. Thus, for the last decade the level of fruit consumption in Ukraine was at the rate of $35-50 \mathrm{~kg}$ per person that is extremely low and does not correspond to scientifically substantiated norms of consumption ( $82 \mathrm{~kg}$ in Ukraine). For comparison: the rate of fruit consumption in the USA, Italy, Germany, the Netherlands is $100-140 \mathrm{~kg}$.

In addition, horticultural industry became highly profitable (Table 2), which will contribute to its development and give impulse for planting new areas of perennial plantations.

Table 2. The development of the Ukrainian horticulture in 2000-2015, \%

\begin{tabular}{lcccc}
\hline \multicolumn{1}{c}{ Indicator } & 2000 & 2005 & 2010 & 2015 \\
\hline Horticulture area, total, thsn. ha & 424.9 & 299.2 & 255.3 & 209.9 \\
\hline Horticulture area processed by lage and middle size farms, thsn. ha. & 277.7 & 146.2 & 94.3 & 61.7 \\
\hline Horticulture area processed by small farm and households and middle size farms, thsn. ha. & 147.2 & 153.0 & 161.0 & 148.2 \\
\hline Harvested, thsn. t & 1452.6 & 1689.9 & 1746.5 & 2153.0 \\
\hline Profitability, $\%$ & -1.1 & 12.7 & 14.9 & 58.3 \\
\hline
\end{tabular}

Source: calculated by authors based on the data obtained from http://www.ukrstat.gov.ua

Finally, agricultural production in Ukraine is shared up between extremely big agricultural producers (Agro Holding), which could process more the one million hectares of the arable per company; middle-size(100-500 ha) and small farms ( 20-100 ha); and households ( size of which limited by $20 \mathrm{ha}$ ). Such diversification is able to provide to the stability of horticulture products and bio-waste supply due to logistics and infrastructure optimization. Importance to notice, the leading position of horticulture productions remains under the households, whose part in the production of this type of products varied within 82-88\%, from 2000 to 2015 (Fig. 2). 


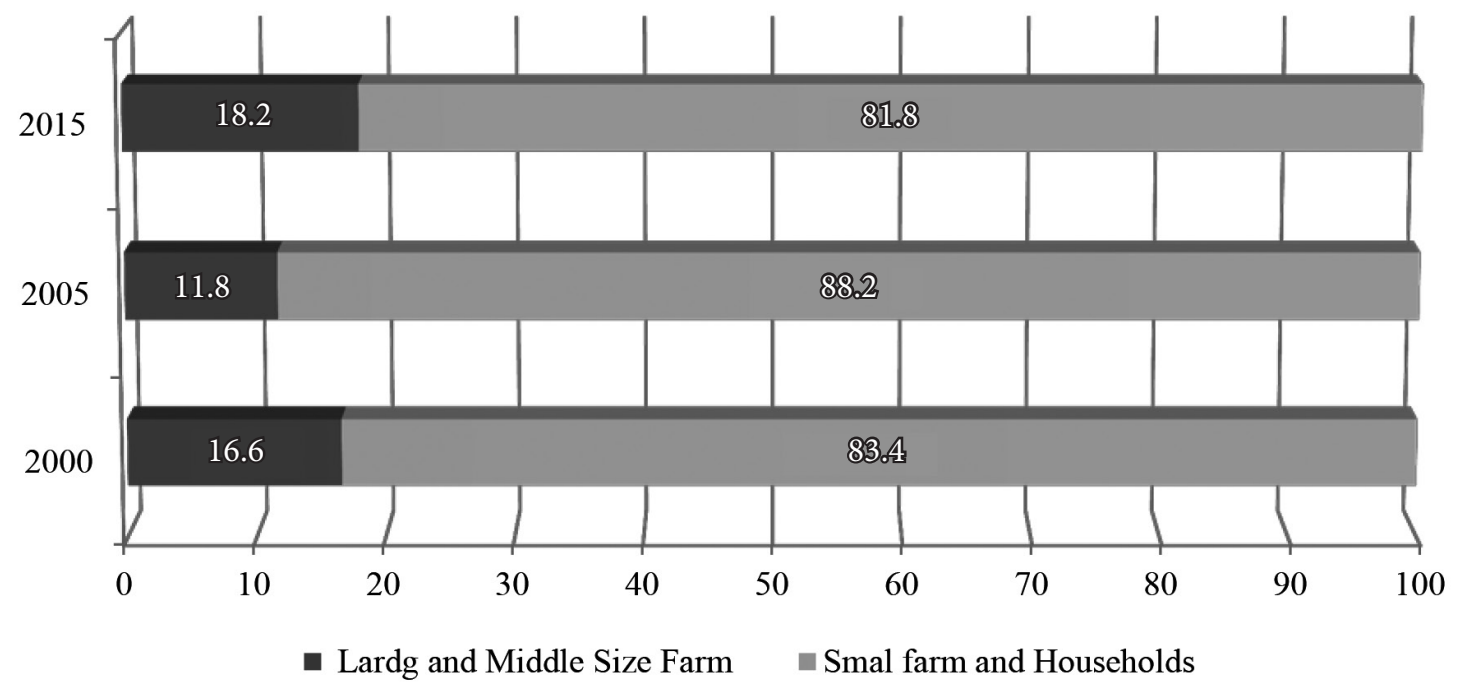

Figure 2. Structure of horticultural production in Ukraine by categories of farms, $\%$

Source: calculated by authors based on the data obtained from http://www.ukrstat.gov.ua

The main objectives of this paper would be focused on the assessment of horticulture bio waste potential focused on its economic, energy and geographical outcomes. Reaching this, it is necessary to evaluate existing potential of horticulture bio wastes production under the application of different production technologies.

The current study may help to solve the problem of identification of horticulture bio-waste potential on the different regional level, especially for the Eastern European countries and Russia.

\section{Materials and Methods}

The combination of different methodologies and data were applied to estimate horticultural bio-waste potential with bioenergy development purpose. Horticultural bio waste is biomass which was obtained in the result of after pruning and trimming of perennial plantations.

2.1. Data Sources In this study, there were used ddata provided by official national statistical authorities such as State Statistics Service of Ukraine. Price index for barrel of Brent oil at London Stock Exchange was used to estimate economic potential of wooden waste based on the average oil price in the third quarter of 2015 . The data sets contains information concerning availability of all areas under perennial plantations in Ukraine corresponding to the farm category. Based on this type of data the evaluation of production potential of bio-waste as well as its geographical availability was calculated.

\subsection{Experimental background}

The study experimental part was carry out on the experimental fields of Uman National University in Ukraine. Obtained result was spread out on the rest country's regions with horticulture production based on the official statistical data. There are gardens of various types with different measurement technologies on the experimental fields

There are gardens of various types with different with different production technologies on the experimental fields reflecting to main existent horticulture production processes and corresponding with different farm types. Large and medium size farms, mainly, plant gardens under intensive gardening technologies on dwarf and semi-dwarf rootstocks (Figure 3, A). In this case, fruit trees enter the fruit for 2-3 years after the laying of the garden. At the same time, households still are keeping a large-scale gardening technology, which is characterized by a larger reserve of wood with the less frequency of trimming trees (Figure 3, B). 


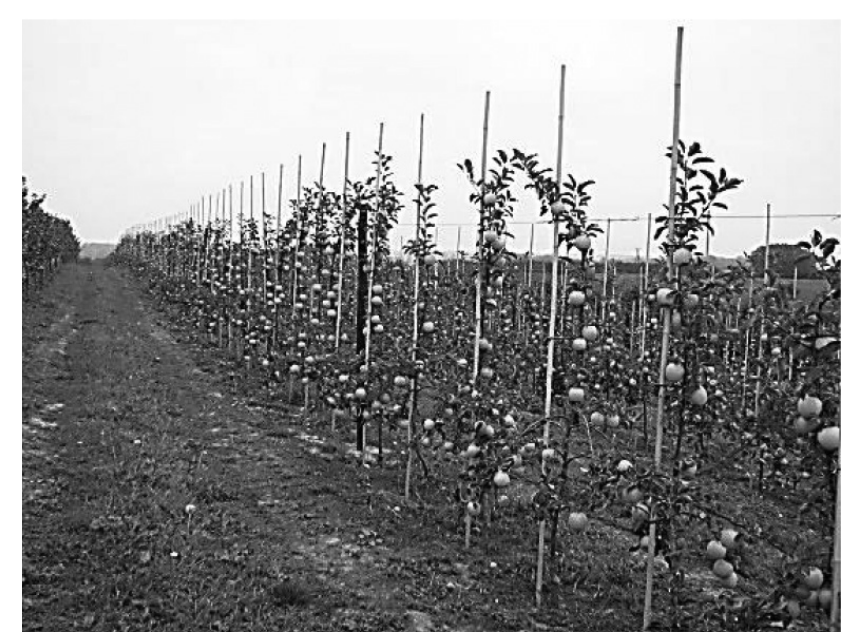

A. Gardens under intensive gardening technologies on dwarf and semi-dwarf rootstocks

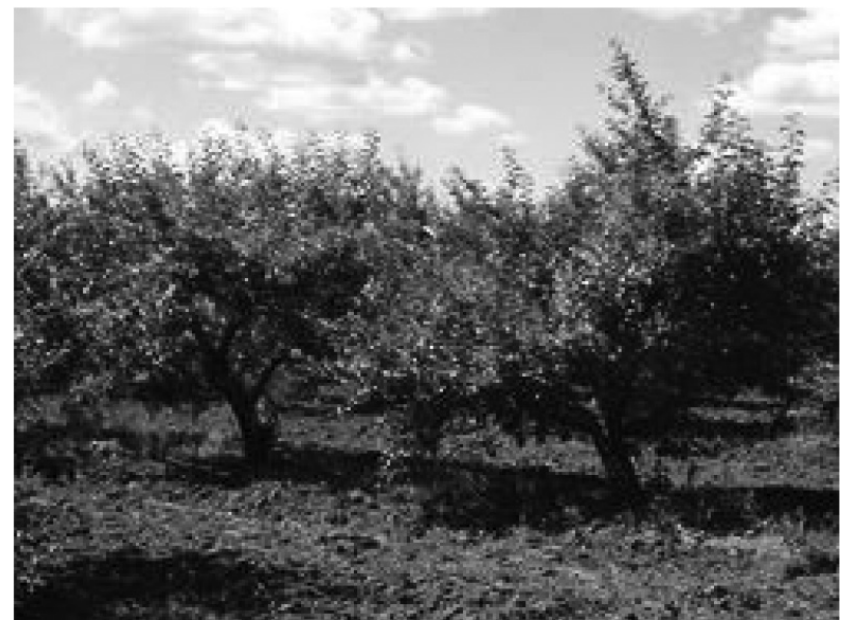

B. Gardens under large-scale gardening technology

Figure 3. Horticulture production technology examples

Differences in the production approaches define computation methods of estimation potential of wooden biowaste in the result of tree trimming and pruning.

Method I. This is the simple method requires involving of 1-2 people. Several trees are selected accidentally in studied area (not less than 10), all biomass is collected manually and weighed. The advantages of this method are simplicity of performing, absence of the need for using of industrial scales. The main problems caused by significant errors of estimation in the result of high deviation within samples (tree size, type of pruning, and etc.) as well as sample size which should include as at least 10 trees.

Method II. Evaluation of bio-waste obtained from the particular plots. The size of plots could variety from 50 to $200 \mathrm{~m}^{2}$. For this study, the plot at $100 \mathrm{~m}^{2}$ was used. All biomass is gathered by hand only inside the area. The advantages of this method are more accurate estimation due to the inclusion of more trees in one sample and averaging the value of each tree in the sample. However, the estimation bio-waste outcomes by plot size is more labour-intensive compared to method I and attracting the means of mechanization is sometimes necessary in the case of measuring under removing a plantation.

Method III. There is evaluation of bio-waste outcome from the whole field or along several lines. Gathering of biomass is done from a large area which allows getting exact results. However, such gathering should be made in a mechanized way.

The first method will be the most reasonable for the case if just one person makes measurements. However, method III evaluation of bio-waste outcome the whole area will be more exact but more costly in the case of machinery using.

It should be noted that since gardens occupy small areas in households, it is more appropriate to measure the amount of wood biomass using method I described in the methodology which does not require labour mechanization. And methods II and III are more reasonably to apply for industrial gardens.

The methods of assessment of energy, economic and geographical impact were used on the second step of this study. 


\subsection{Theoretical background}

The theoretical part of methodology based on the previous research (Geletukha G.G., Zhieliezna T.A. and others, 2010) is proved three possible ways of biomass potential determination:

- physical availability. There are two main variables of estimation of this potential: theoretical estimation of the total volume of biomass which can be obtained from currently processed production areas; and technical capacity defines by certain technical and structural conditions and current technological capabilities. The physical availability was estimated through the practical approaches describing above. It should be taken into account that availability coefficient for waste is equal to 0.9 when calculating physical availability of wood biomass.

- energy potential determines by thermodynamic properties of materials. Recalculation in conventional fuel was done through the heat of combustion of $10 \mathrm{MJ} / \mathrm{kg}$ (natural humidity) was apply for wooden waste.

- economic potential is the part of technical potential that meets the criteria of economic expediency under the given conditions. Economic potential of horticulture wooden waste was estimated using a cost expression of the oil equivalent of one ton of conventional fuel. The calculation was done through the application of the next equations:

$$
\text { Ек }=(P o t \times \kappa) \times P,
$$

where: Ек - expression of economic potential;

Pot - physical availability;

$k$ - transmission coefficient of conditional fuel (tone) into the oil equivalent (barrels), where

$k=4.79$;

$P$ - oil price \$ per barrel, where

$\mathrm{P}=50.7$

Geographic potential of horticulture wooden waste was determined applying method of grouping which made it possible to divide areas of Ukraine into zones according to physical availability of the wood waste following up to the work done by Dornburg et al (2001).

\section{Results}

The potential scope of wooden waste was calculated on the basis of data received by the practical way, using the methods of economic analysis and processing of statistical data. The available potential of horticulture wooden waste was determined in the process of study.

The volume of potential physically available wooden waste per one hectare of cultivated area was obtained in the result of experiments on the base of gardens in the Uman National University of Horticulture (Table 3)

Table 3. Horticulture wooden waste outcomes: experimental estimations

\begin{tabular}{|c|c|c|c|}
\hline Experiment number & Method I & Method II & Method III \\
\hline 1 & 1.993 & 4.588 & 4.844 \\
\hline 2 & 2.330 & 5.012 & 4.698 \\
\hline 3 & 2.071 & 4.870 & 5.032 \\
\hline 4 & 2.487 & 4.495 & 4.760 \\
\hline 5 & 2.109 & 4.835 & 4.266 \\
\hline Average per one ha & 2.200 & 4.760 & \\
\hline
\end{tabular}


It was found that the average outcome of wooden waste is $4.76 \mathrm{t} / \mathrm{ha}$ under intensive growing technology while it is only about $2.2 \mathrm{t} /$ ha in the case of a large-scale gardening technology application (Table 4).

Theoretical potential of horticulture wooden waste formed after their pruning and eradicating is possible to calculate on the basis of given data (Table 4).

Table 4. Physically available horticulture wooden waste by farm types, tones

\begin{tabular}{lcc}
\hline \multicolumn{1}{c}{ Indicator } & Total & Limited by technical capasity \\
\hline Large and middle size farms & 293.7 & 264.3 \\
\hline Small farms and Households & 326.0 & 293.4 \\
\hline All categories & 619.7 & 557.7 \\
\hline
\end{tabular}

Given result were used to found potential of physically available horticulture wooden wastes on the country level. There is around 620 thousand tons annually. Physical availability of wooden waste per region is reflected below in the part of geographical potential.

However, accessible wooden waste is limited by current technical capacity on the level around 558 thousand tons, annually since availability coefficient for wood waste is set at the rate of 0.9

Amount of energy potential from wooden waste in horticulture industry in Ukraine was estimated on the level of 191.0 thousand tons of conditional fuel (c.f.) per year (Fig.4). Which can be successfully used by farmers covering their own needs. Following to the fact that nowadays horticulture wooden waste in Ukraine is not already considered as a commodity product and is usually simply burned at the edge of the field, and horticulture industry has great prospects for development, then its energy use can be a powerful tool for replacing of fossil fuels in the future.
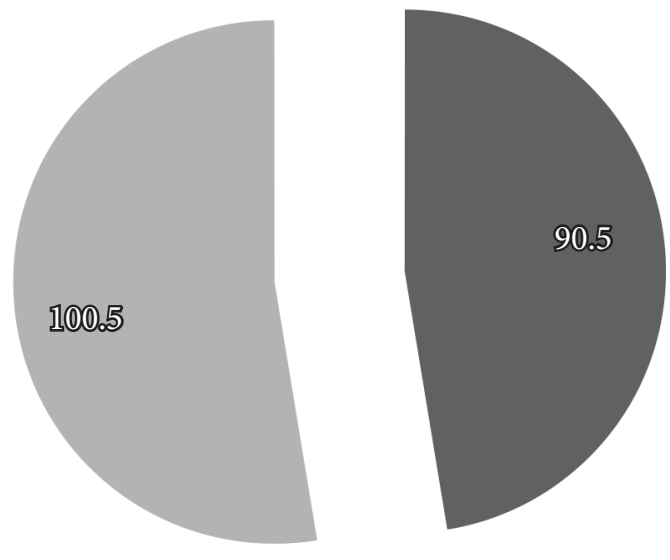

- Lardg and Middle Size Farm

- Smal farm and Households

Fig. 4. Energy potential of wooden waste in horticulture industry, c.f. thousand tons.

Source: own calculation

Using of horticulture wooden waste also may bring an economic effect, which is lied in:

1) reduction of dependence from purchased energy sources;

2) decrease in cost price of agricultural products;

3) mastering production of new types of products;

4) coming out to new markets.

We calculated that economic potential of horticulture wood biomass after can reach 46438 thousand of UAN (around \$1.5 mill US dollar) annually while using the methodology with taking cost expression of oil equivalent of one tonne of conventional fuel (Fig.5) . 


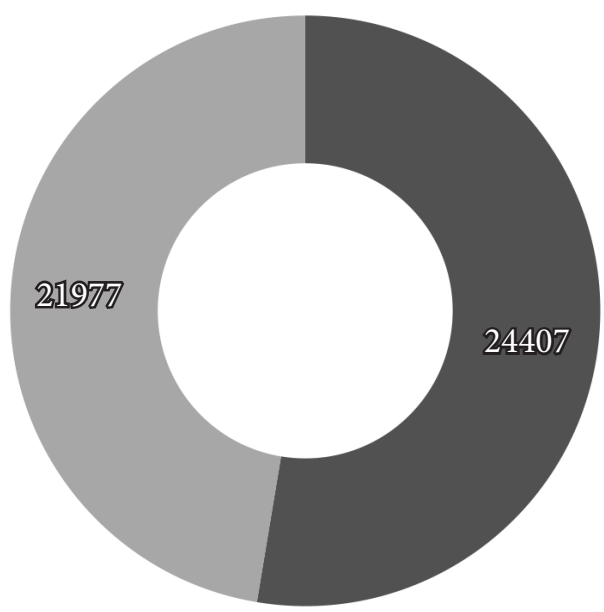

- Lardg and Middle Size Farm $\quad$ Smal farm and Households

Figure 5. Economic potential of horticulture wooden waste by farms type, thsn. UAN.

Source: own calculation

Finally, analysis of geographic potential of horticulture wooden waste in Ukraine was performed.

Geographic potential of horticulture wooden waste in Ukraine is directly dependent on the location of horticulture production area (Table 5, Fig. 6).

All regions could be united into the three main geographical groups due to the production potential of horticulture wooden waste:

1) with potential of wood biomass under 20 thsn. t.;

2) with potential of wood biomass from 20 to 40 thsn. t.;

3) with potential of wood biomass over than 40 thsn. $t$.

Table 5. Physical availability of horticulture wooden waste by group

\begin{tabular}{ccc}
\hline under 20 thsn. $\mathrm{t}$ & from 20.1 thousand tons to 39.9 thsn. T. & over 40 thsn t. \\
\hline Volyn oblast & Lviv oblast & Vinnytsia oblast \\
Ternopil oblast & Zakarpattia oblast & Chernivtsi oblast \\
Zhytomyr oblast & Ivano-Frankivsk oblast & Khmelnytskyi oblast \\
Poltava oblast & Rivne oblast & Dnipropetrovsk oblast \\
Cherkasy oblast & Kyiv oblast & \\
Kirovohrad oblast & Odesa oblast & \\
Mykolaiv oblast & Kherson oblast & \\
Chernihiv oblast & Zaporizhzhia oblast & Kharkiv oblast \\
Sumy oblast & Donetsk oblast & \\
Luhansk oblast &
\end{tabular}

Source: own calculation

Region with the highest potential of wooden waste feedstock includes Vinnytsia, Chernivtsi, Khmelnytskyi and Dnipropetrovsk oblast. The third group (with the poorest potential of wooden waste feedstock) contains 10 regions, and the second group includes 9 regions. This confirm the fact that the biggest part of the territory of Ukraine has favourable conditions fo bio-based energy development. 


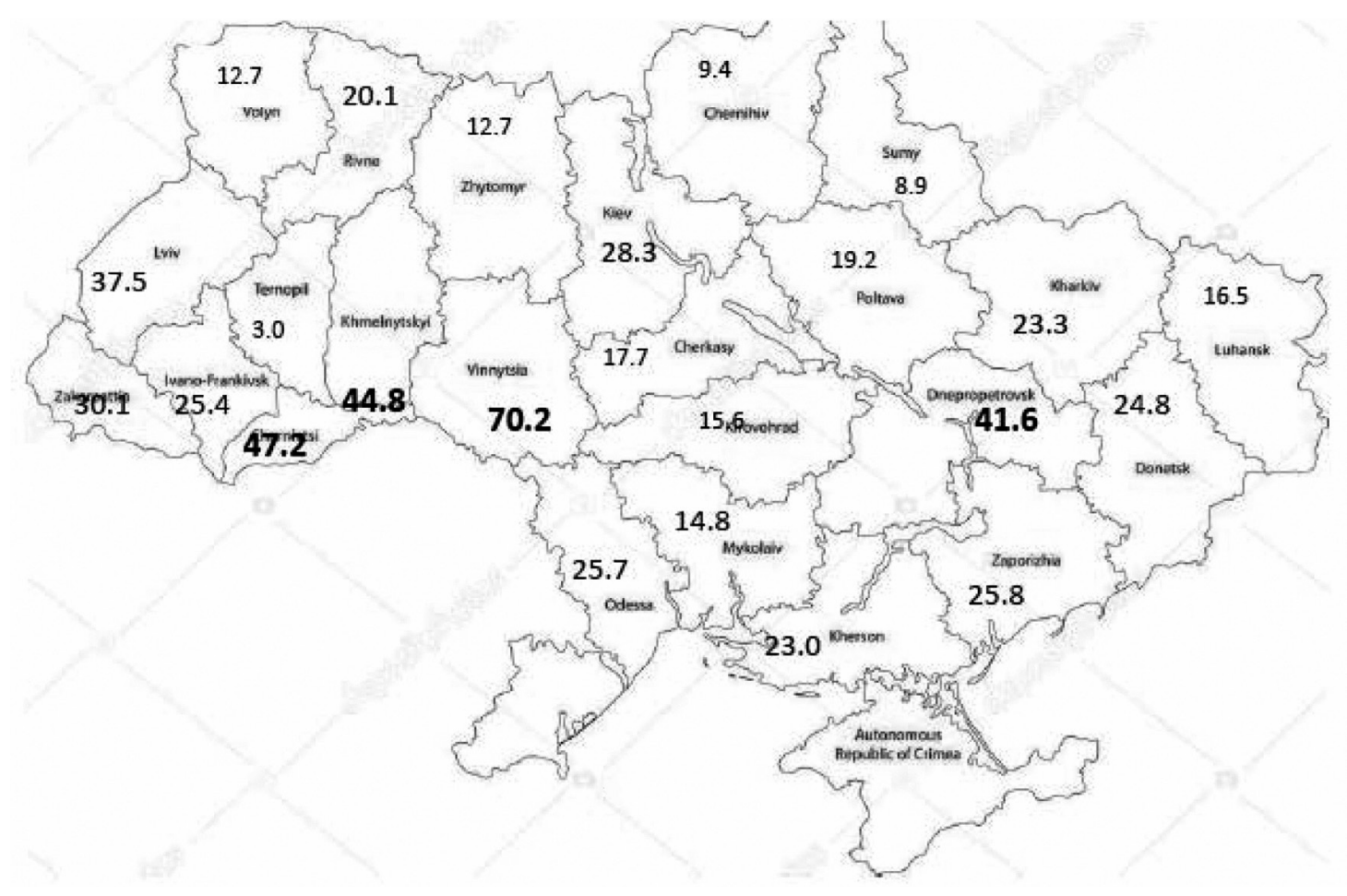

Figure 6. The geographic potential of horticulture wooden waste by region, thsnd. T

Source: own calculation

Analysis of geographic potential on the regional level of Ukraine affects the formation of production and service infrastructure, creation of logistics centres; non-profit cooperatives on processing of horticulture wooden waste, on determine necessary capacities, etc.

Thus, summing up the above, one can conclude that there is significant potential of horticulture wooden waste in Ukraine.

\section{Discussion}

At the same time, there are considerable barriers in the development of energy using horticulture wooden waste formed after their pruning and eradicating in Ukraine. According to the researches of Bioenergy Association of Ukraine (Geletukha G., 2017), the main barriers can be classified by the following groups:

- technical and organizational - the need for additional technological equipment, at all stages of production of wood mass from pruning and gathering to its using; problems in organization of the logistics chain; a small amount of waste in one supplier, and therefore the need to join into cooperatives; non-developed infrastructure in the regions;

- normative - lack of state standards for solid biofuel; administrative barriers while creating a business concerning selling of wood waste as a fuel;

- economic and financial - the need in significant investments for purchasing of equipment; high credit rates and high cost price of finished biofuel;

- structural - unformed biomass market as fuel in Ukraine; competition with the shadow firewood market; absence of service companies that provide services in gathering, crushing and transportation of biomass; state monopoly on supply of wood biofuel to existing consumers;

- cultural - complexity of activity coordination among all the members of production chain; unwillingness of farmers to unite in service cooperatives and their misunderstanding of economic benefits from selling of their own waste, etc. 
It should be highlighted that wooden waste utilization may have a significant social impact. Though this study was not focused to investigate it but obtained result could be used as a background for further study of the social effects of wooden biomass using.

Social effect. Use of horticulture wooden waste in horticulture also has a social effect. It shows itself in:

- diversification of rural economy;

- creation of new organizational structures and workplaces;

- development of rural areas;

- improvement of population health;

- ensuring welfare and life quality of rural population.

Thus, for example, nowadays Vinnytsia region (occupies the first place by potential of wood biomass in the field of horticulture) has 170 boiler houses on solid biofuel with a total capacity of $125 \mathrm{MW}$, in particular, in 2016 the largest boiler house on wood in Ukraine with the capacity of 5.2 MW was built in Vinnytsia, which, in addition to reducing the need of the region's population in energy from traditional sources, causes creation of new working places, rising of people's income, development of rural areas, etc.

Favourable conditions for the development of bioenergy using biomass from horticulture wooden waste were created in Ukraine, consisting of:

- significant potential of horticulture wooden waste;

- availability of a large number of biofuel consumers;

- support of the state policy of energy saving in the country and diversification of the ways of supply biofuel;

- availability of domestic equipment for gathering, crushing and burning wood in Ukraine.

\section{Conclusions}

There is a rapid development of bioenergy in Ukraine, as well as in developed countries of the world. It is necessary to study potential of horticulture wooden waste taking into account that horticulture is a well-developed industry of economy. At present, biomass occupies only $2.2 \%$ in the structure of renewable energy sources in Ukraine, while this rate is $28-64 \%$ in the EU. However, specific part of biomass, biofuel and waste should increase to $11.5 \%$ by 2035 according to the New Energy Strategy of Ukraine.

Use of horticulture wooden waste in gardening, except economic effect also may have strong ecological and social effect. Combination of these effects requires further development of bioenergy using horticulture wooden waste in Ukraine.

Significant part of the territory has favourable conditions for the development of bioenergy on the basis of horticulture wooden waste. Besides, such factors will contribute to the development as significant potential of horticulture wooden waste; availability of a large number of biofuel consumers; support of the state policy of energy saving in the country and diversification of the ways of supply biofuel; availability of domestic equipment for gathering, crushing and burning wood in Ukraine.

Barriers in the development of energy using horticulture wooden waste formed after their pruning and eradicating can be divided into the following groups: technical, organizational, financial, economic, normative, structural and cultural.

\section{Acknowledgments}

The experimental part of this study was carried out under project "uP_running" (HORIZON 2020) on the basis of Uman National University of Horticulture, Ukraine. Besides, this work was supported by AgroBioTech Research Centre built in accordance with the project Building "AgroBioTech" Research Centre ITMS 26220220180. 


\section{References}

"Ukraine: Prospects for Development". Consensus-forecast of the Ministry of Economic Development and Trade of Ukraine. http:// documents.tips/economy\%finance/\%2015\%2019\%\%55bd32c2c7b92.html

A manual for organizing field measurements of the amount of biomass from waste trimming and stump extraction. The Internet. Access: http://ua.up-running.eu.

Cardoso, P. P.; Swan, A.; Mendes, R. 2018. Exploring the key issues and stakeholders associated with the application of rainwater systems within the Amazon Region, Entrepreneurship and Sustainability Issues5(4): 724-735. https://doi.org/10.9770/jesi.2018.5.4(2)

Dobrovolskienė, N.; Tvaronavičienė, M.; Tamošiūnienė, R. 2017. Tackling projects on sustainability: a Lithuanian case study, Entrepreneurship and Sustainability Issues 4(4): 477-488. https://doi.org/10.9770/jesi.2017.4.4(6)

Dornburg, Veronika, Detlef, van Vuuren, Gerrie, van de Ven, Hans, Langeveld, Marieke, Meeusen, Martin, Banse, Mark, van Oorschot, Jan, Ros, Gert, Jan, van den Born, Harry, Aiking, Marc, Londo, Hamid, Mozaffarian, Pita, Verweij, Erik, Lysen, André, Faaij. 2010. Bioenergy revisited: Key factors in global potentials of bioenergy. Energy Environ. Sci., 3: 258-267.

Dornburg, Veronika, Faaij, André, P.C. 2001. Efficiency and economy of wood-fired biomass energy systems in relation to scale regarding heat and power generation using combustion and gasification technologies. Biomass and Bioenergy, 21(2): 91-108.

Eurostat. The Internet. Access: http://ec.europa.eu/eurostat/web/energy/data/database

Field, Christopher B., Campbell, J. Elliott, Lobell, David B. 2008. Biomass energy: the scale of the potential resource. Trends in Ecology \& Evolution, 23(2): 65-72.

Geletukha, G.G., Zhelezna, T.A., Zhovmir, M.M., Matveev, Y.B., Drozdova, O.I. 2010. Estimation of the energy potential of biomass in Ukraine. Industrial heat engineering, 32(5): 58-65.

Gustavsson, L., Holmberg, J., Dornburg, V., Sathre, R., Eggers, T., Mahapatra, K., Marland, G. 2007. Using biomass for climate change mitigation and oil use reduction. Energy Policy, 35(11): 5671-5691.

Halla, D.O., Scrasea, J.I. 1998. Will biomass be the environmentally friendly fuel of the future? Biomass and Bioenergy, 15(4-5): 357-367.

Hoogwijk, Monique, Faaij, André, Bas, Eickhout, Bert, de Vries, Turkenburg, Wim. 2005. Potential of biomass energy out to 2100 , for four IPCC SRES land-use scenarios. Biomass and Bioenergy, 29(4): 225-257.

Iorio, M.; Monni, S.; Brollo, B. 2018. The Brazilian Amazon: a resource curse or renewed colonialism?, Entrepreneurship and Sustainability Issues 5(3): 438-451. https://doi.org/10.9770/jesi.2018.5.3(2)

Ivanov, D.; Belyaeva, E.; Kurilova, A.; Popkova, E. 2018. Models for the interaction between space services providers and manufacturers of space vehicles, Entrepreneurship and Sustainability Issues 5(4): 846-857. https://doi.org/10.9770/jesi.2018.5.4(10)

Ivanova, S.; Latyshov, A. 2018. Sustainable entrepreneurship: agrarian policy in South Korea, Entrepreneurship and Sustainability Issues 5(4): 748-760. https://doi.org/10.9770/jesi.2018.5.4(4)

Kiseláková, D.; Šofranková, B.; Čabinová, V.; Onuferová, E. 2018. Competitiveness and sustainable growth analysis of the EU countries with the use of Global Indexes' methodology, Entrepreneurship and Sustainability Issues 5(3): 581-599. https://oi.org/10.9770/ jesi.2018.5.3(13)

Kisel'áková, D.; Šofranková, B.; Čabinová, V.; Onuferová, E. 2018. Competitiveness and sustainable growth analysis of the EU countries with the use of Global Indexes' methodology, Entrepreneurship and Sustainability Issues 5(3): 581-599. https://oi.org/10.9770/ jesi.2018.5.3(13)

Mola-Yudego, Blas, Arevalo, Javier, Díaz-Yáñez, Olalla, Dimitriou, Ioannis, Freshwater, Elliot, Haapala, Antti, Khanam, Tahamina, Selkimäki, Mari. 2017. Reviewing wood biomass potentials for energy in Europe: the role of forests and fast growing plantations. Biofuels, 8(4).

Monni, S.; Iorio, M.; Realini, A. 2018. Water as freedom in the Brazilian Amazon, Entrepreneurship and Sustainability Issues 5(4): 812-826. https://doi.org/10.9770/jesi.2018.5.4(8)

Muniz, J.; de Melo, M. d.; Liberato, M. A.; Wahnfried, I.; Vieira, G. 2018. Towards sustainability: allowance rights for using water resources in Amazonas State of Brazil, Entrepreneurship and Sustainability Issues5(4): 761-779. https://doi.org/10.9770/jesi.2018.5.4(5) 
New Energy Strategies of Ukraine until 2035: "Security, Energy Efficiency, Competitiveness". Project, June 1, 2017. http://mpe.kmu. gov.ua/minugol/control/uk/doccatalog/list?currDir=50358

Plenkina, V.; Andronova, I.; Deberdieva, E.; Lenkova, O.; Osinovskaya, I. 2018. Specifics of strategic managerial decisions-making in Russian oil companies, Entrepreneurship and Sustainability Issues 5(4): 858-874. https://doi.org/10.9770/jesi.2018.5.4(11)

Rocha, G. d.; Neves, M. B. 2018. Hydroelectric projects and territorial governance in regions of The State of Pará, Brazilian Amazon, Entrepreneurship and Sustainability Issues 5(4): 712-723. https://doi.org/10.9770/jesi.2018.5.4(1)

Sarana, V.V. 2006. Justification of main parameters of the shredder of branches of the compacted garden. Dissertation abstract for obtaining PhD in Technical Sciences. Kyiv.

Security of Russia. Legal, socio-economic and scientific-energy aspects. Energy security. (Problems of the functioning and development of the electric power industry). 2001. Moscow: Knowledge.

Shakhovskaya, L.; Petrenko, E.; Dzhindzholia, A.; Timonina, V. 2018. Market peculiarities of natural gass: case of the Pacific Region, Entrepreneurship and Sustainability Issues 5(3): 555-564. https://doi.org/10.9770/jesi.2018.5.3(11)

Šincāns, E., Ignatjeva, S., Tvaronavičienè, M. (2016), Issues of Latvian Energy Supply Security: Evaluation of Criminal Offences in Latvia's Electricity Market, Economics and Sociology 9(4): 11-25. http://dx.doi.org/10.14254/2071-789X.2016/9-4/1

Song, Nianfu, and Francisco X. Aguilar. 2017. Woody biomass energy efficiency pathways: public policy implications. Biofuels 8.4: 473-483.

Statistical Yearbook of Ukraine. State Statistics Service of Ukraine. The Internet. Access: http://www.ukrstat.gov.ua

Strategy of the balanced regional development of Vinnytsia region up to 2020. Vinnytsia Regional State Administration. 2015. The Internet. Access: http://www.vin.gov.ua/invest/rehionalni-prohramy-rozvytku/624-stratehiia-zbalansovanoho-rehionalnoho-rozvytkuvinnytskoi-oblasti-na-period-do-2020-roku-nova-redaktsiia

Stuchynska, N.P. 2016. Energy Security of Ukraine: the essence and possibilities of realization. Investments: practice and experience, 9: 104-108.

Tvaronavičienė, M. 2018. Towards sustainable and secure development: energy efficiency peculiarities in transport sector, Journal of Security and Sustainability Issues 7(4): 719-725. https://doi.org/10.9770/jssi.2018.7.4(9)

Tvaronavičienė, M.; Nesterova, K.; Kováčik, V. 2017. Energy security and long-term energy efficiency: case of selected counties, Journal of Security and Sustainability Issues 7(2): 349-357. https://doi.org/10.9770/jssi.2017.7.2(14)

Twidell, J. and Weir, T., 2015. Renewable energy resources. Routledge. 